\title{
Changes in the Anti-Allergic Activities of Sesame by Bioconversion
}

\author{
Tae-Dong Jung ${ }^{1,+}{ }^{\dagger}$, Sun-Il Choi ${ }^{1,+}$, Seung-Hyun Choi ${ }^{1}$, Bong-Yeon Cho ${ }^{1}$, Wan-Sup Sim ${ }^{1}$, \\ Han- Xionggao ${ }^{1}$, Sang Jong Lee ${ }^{2}$, Seon Ju Park ${ }^{2}$, Dan-Bi Kim ${ }^{3}$, Young-Cheul Kim ${ }^{4}$, \\ Jin-Ha Lee ${ }^{1, *}$ and Ok-Hwan Lee ${ }^{1, * \text { (D) }}$ \\ 1 Department of Food Science and Biotechnology, Kangwon National University, Chuncheon 24341, Korea; \\ lgtjtd@naver.com (T.-D.J.); docgotack89@hanmail.net (S.-I.C.); zzaoszz@naver.com (S.-H.C.); \\ bongyeon.cho92@gmail.com (B.-Y.C.); simws9197@naver.com (W.-S.S.); xionggao414@hotmail.com (H.-X.) \\ 2 STR Biotech Company, LTD., Chuncheon 24232, Korea; sj@strbiotech.co.kr or 1sj@strbiotech.co.kr (S.J.L.); \\ coco4649@strbiotech.co.kr (S.J.P.) \\ 3 Korea Food Research Institute, Wanju-gun, Jeollabuk-do 55365, Korea; Kim.Dan-bi@kfri.re.kr \\ 4 Department of Nutrition, University of Massachusetts Amherst, Amherst, MA 01003, USA; \\ yckim@nutrition.umass.edu \\ * Correspondence: tre98@hanmail.net (J.-H.L.); loh99@kangwon.ac.kr (O.-H.L.); Tel.: +82-010-7554-4125 (J.-H.L.); \\ +82-33-250-6454 (O.-H.L.); Fax: +82-33-253-0149 (J.-H.L.); +82-33-259-5565 (O.-H.L.) \\ + These authors contributed equally to this work.
}

Received: 18 December 2017; Accepted: 13 February 2018; Published: 14 February 2018

\begin{abstract}
Sesame is an important oilseed crop, which has been used as a traditional health food to ameliorate the prevention of various diseases. We evaluated the changes in the anti-allergic activities of sesame by bioconversion. SDS-PAGE of non-fermented sesame proteins showed major allergen bands, while that of fermented sesame showed only a few protein bands. Additionally, we investigated the effectiveness of fermented sesame by bioconversion in tumor necrosis factor- $\alpha$ (TNF- $\alpha$ )- and interferon- $\gamma$ (IFN- $\gamma$ )-induced HaCaT cells. In HaCaT cells, fermented sesame inhibited the mRNA expression of interleukin-6 (IL-6) and interleukin-1 $(\mathrm{IL}-1 \beta$ ), thymus and macrophage-derived chemokine (MDC/CCL22), activation-regulated chemokine (TARC/CCL17), and intercellular adhesion molecule-1 (ICAM-1). Moreover, fermented sesame inhibited the activation of nuclear factor- $\mathrm{KB}(\mathrm{NF}-\mathrm{KB})$ and signal transducer and activator of transcription 1 (STAT1). Fermented sesame exerts anti-allergic effects by suppressing the expression of chemokines and cytokines via blockade of NF- $\mathrm{kB}$ and STAT1 activation.
\end{abstract}

Keywords: atopic dermatitis; bioconversion; Sesamum indicum L.; skin inflammation; anti-allergic

\section{Introduction}

Sesame (Sesamum indicum L.) is composed of about 50\% lipid, 15\% carbohydrate, 5\% moisture, and $15 \%$ protein. The sesame seed is one of the most important oil crops cultivated in India, China, Sudan, and other Asian countries. In addition, the sesame seed has been used in traditional medicine for its anti-aging and anti-hepatotoxic effects. The oxidative stability of sesame oil is due to the presence of lignan compounds such as sesamol, sesamin, and sesamolin [1]. Several studies have reported the biological activity of lignan compounds, which include anti-lipid peroxidation [2], anticancer activity towards MCF-7 cells [3], and a protective effect against sepsis in rats [4]. However, sesame seed food allergies are becoming an increasingly recognized health issue, especially in developed countries, including the European Union [5]. The major allergen proteins in sesame have been identified in Canada and the United State: Ses i $1(9 \mathrm{kDa})$ and Ses i $2(7 \mathrm{kDa})$ are members of the $2 \mathrm{~S}$ albumin family, while Ses i $3(45 \mathrm{kDa}) 7 \mathrm{~S}$ globulin, Ses i $4(17 \mathrm{kDa})$, and Ses i $5(15 \mathrm{kDa})$ are members of the $2 \mathrm{~S}$ oleosin family. Sesame allergen proteins have been identified by SDS-PAGE, mass spectrometry, and immunoblotting [6,7]. 
Atopic dermatitis (AD) is a common chronic inflammatory disorder of the skin. The recognition of food allergens by antigen-presenting cells in individuals with eczema could be an important mediator of food sensitization and food allergy.

Keratinocytes are the main epidermal cells that play a critical role in the occurrence of AD. Exposure of keratinocytes to tumor necrosis factor- $\alpha$ (TNF- $\alpha$ ) and interferon- $\gamma$ (IFN- $\gamma$ ) leads to the abnormal expression of cytokines, chemokines, and adhesion molecules, such as ICAM-1, which is considered to increase the infiltration of monocytes into the site of inflammation in the skin [8]. Macrophage-derived chemokine (MDC/CCL22) and thymus and activation-regulated chemokine (TARC/CCL17) and are members of the chemokine subfamily and are produced by various cell types, such as keratinocytes [9]. Since TARC is a ligand for CCR4, which is predominantly expressed in Th2 lymphocytes, it selectively controls the migration of Th2 lymphocytes into the site of inflammation [10]. MDC is constitutively produced by B cells, dendritic cells, keratinocytes, and macrophages. Thus, TARC and MDC play an important role in the development of skin diseases such as atopic dermatitis. TARC and MDC promoters contain STAT1 and NF- $\mathrm{kB}$ binding sequences, and these transcription factors may mediate the transcription of these genes [11].

Bioconversions such as fermentation, carried out by microorganisms and enzymes, may produce beneficial bioactive compounds. Apart from improving the bioavailability of nutrients, it has been hypothesized that fermentation regulates immunogenicity and possibly the reduction of allergenicity [12]. Our previous studies demonstrated that the used bioconversion process amplifies the antioxidant activity and bioactive compounds in sesame [13]. Many studies have demonstrated that soybean allergen degradation occurs during fermentation of soybean food [14,15]. However, an effect of sesame by bioconversion on the anti-allergic and anti-inflammatory activities has not been reported.

In this study, we evaluated the degradation of major sesame Ses i allergens by the bioconversion of sesame. Furthermore, we examined the anti-allergic activities of non-fermented and fermented sesame, TNF- $\alpha$ - and IFN- $\gamma$-induced production of cytokines (IL- $1 \beta$ and IL- 6 ) and chemokines (TARC, MDC), and gene expression (IL-1 $\beta$, IL6, ICAM-1, TARC, and MDC) via regulation of NF-KB and STAT1 signaling pathways in $\mathrm{HaCaT}$ cells.

\section{Materials and Methods}

\subsection{Chemicals}

Fetal bovine serum (FBS), Dulbecco's modified Eagle's medium (DMEM), and phosphate buffer saline (PBS, pH 7.4) were obtained from Gibco (Gaithersburg, MD, USA). Recombinant human TNF- $\alpha$ and IFN- $\gamma$ were obtained from R\&D System Inc. (Minneapolis, MN, USA). ELISA kits for human IL-1 $\beta$, IL6, MDC/CCL22, and TARC/CCL17 were purchased from R\&D System. Antibodies against IKB $\alpha$, phospho-STAT1(Ser727), STAT1, phospho-NF-кB p65(Ser536) were purchased from Cell Signaling Technology (Beverly, MA, USA).

\subsection{Sample Preparation}

Sesame was harvested in August, 2014 and provided by the National Institute of Crop Science (Milyang, Korea). Sesame was fermented with Lentinula edodes using a fermentation system (STR biotech, Chuncheon, Korea). Briefly, L. edodes fungal mycelia were isolated from the mushroom fruit body and cultured in potato dextrose agar medium (PDA, Difco Laboratory, Detroit, MI, USA). The genetic identity of the fungus was confirmed by the Korean Center of Microorganisms (Seoul, Korea). The mycelia cultured on PDA media were inoculated in $50 \mathrm{~mL}$ of a liquid medium containing $2 \%$ glucose, $0.5 \%$ yeast extract, $0.5 \%$ soy peptone, $0.2 \% \mathrm{KH}_{2} \mathrm{PO}_{4}, 0.05 \% \mathrm{MgSO}_{4}$, and $0.002 \% \mathrm{FeSO}_{4}$. The experiments were conducted in $250 \mathrm{~mL}$ Erlenmeyer flasks at $28^{\circ} \mathrm{C}$ for 5 days in a rotary shaker, and the resulting broth was used to seed the main liquid culture. A liquid culture medium containing sesame was treated with amylase and cellulase at $60^{\circ} \mathrm{C}$ for $60 \mathrm{~min}$ for the enzymatic digestion of particulate materials containing carbohydrate. Subsequently, the culture mass was adjusted by bringing the $\mathrm{pH}$ to 6.0 with $\mathrm{HCl}$, and sterilization was 
done in the autoclave. The main investigations with the liquid culture were started in a $5 \mathrm{~L}$ fermenter (working volume of $3 \mathrm{~L}$ ) at $28^{\circ} \mathrm{C}$ and $150 \mathrm{rpm}$ by inoculating with the cultured mycelia (10\%). After 7 days, the culture was treated with an enzyme mixture containing cellulase, hemicellulase, pectinase, glucanase, mannase, and arabinase at $50{ }^{\circ} \mathrm{C}$ for $60 \mathrm{~min}$, for cell wall lysis. The enzyme-treated culture mass was then extracted at $90{ }^{\circ} \mathrm{C}$ after $1 \mathrm{~h}$ and freeze-dried to a solid material. Non-fermented and fermented sesame (500 mg) were mixed with $25 \mathrm{~mL}$ of PBS, and the mixture was sonicated for $60 \mathrm{~min}$. The mixture was centrifuged at $3000 \times g$ for $15 \mathrm{~min}$, and the supernatant was filtered through a $0.22 \mu \mathrm{m}$ PVDF filter (Millex-HV, Millipore, Bedford, MA, USA).

\subsection{Sodium Dodecyl Sulfate-Polyacrylamide Gel Electrophoresis (SDS-PAGE)}

The molecular weight distribution was determined using SDS-PAGE according to a previously described method with some modifications [16]. A loading buffer (150 mM NaCl, $50 \mathrm{mM}$ Tris- $\mathrm{HCl}, 1 \%$ Trizol, $0.1 \%$ SDS, $0.25 \%$ sodium deoxycholate, and 2-mercaptoethanol) was added to non-fermented and fermented sesame (30 $\mathrm{gg}$ total protein), and the mixture was boiled in a water bath for $5 \mathrm{~min}$. The supernatant was electrophoresed using a 5\% stacking gel and 15\% separating SDS-polyacrylamide gel, after which the gel was stained with Coomassie blue.

\subsection{Cell Culture and Cell Viability Assay}

The human keratinocyte HaCaT cell line obtained from the cell line service (CLS) (Eppelheim, Germany) was maintained in DMEM supplemented with 10\% FBS, penicillin $(100 \mathrm{U} / \mathrm{mL})$, and streptomycin $(100 \mu \mathrm{g} / \mathrm{mL})$ in a humidified, $5 \% \mathrm{CO}_{2}$ incubator at $37{ }^{\circ} \mathrm{C}$.

Cell viability was assessed using an XTT(2,3-bis-2-methoxy-4-nitro-5-sulfophenyl-2H-tetrazolium5-carboxanilide) assay (Welgene, Seoul, Korea), performed according to the manufacturer's instructions. After pre-incubation of $\mathrm{HaCaT}$ cells for $24 \mathrm{~h}$ in a 96 -well plate $\left(1 \times 10^{5}\right.$ cells/well), the cells were treated with non-fermented sesame (NS) and fermented sesame (FS) (50, 100, $200 \mu \mathrm{g} / \mathrm{mL})$ and /or TNF- $\alpha$ $(10 \mathrm{ng} / \mathrm{mL}) / \mathrm{IFN}-\gamma(10 \mathrm{ng} / \mathrm{mL})$ for $24 \mathrm{~h}$. The XTT reagent was added, and the plate was incubated for $4 \mathrm{~h}$. The absorbance was measured at $450 \mathrm{~nm}$ using a microplate reader (Molecular Devices, Sunnyvale, CA, USA).

\subsection{Reverse Transcription-Polymerase Chain Reaction (RT-PCR)}

HaCaT cells $\left(1 \times 10^{6}\right.$ cells/well $)$ were treated with TNF- $\alpha /$ IFN- $\gamma$ or with medium alone in the presence or absence of NS or FS for $24 \mathrm{~h}$. The total RNA was extracted using the Trizol reagent (Invitrogen, Carlsbad, CA, USA) according to the manufacturer's instructions. For cDNA synthesis, $1 \mu \mathrm{g}$ of total RNA was mixed with oligo dT primers using Maxime RT premix (iNtRON Biotechnology, Sungnam, Korea) and water to a total volume of $20 \mu \mathrm{L}$ and incubated. The PCR amplification conditions were as follows: IL- $1 \beta, 95{ }^{\circ} \mathrm{C}, 30 \mathrm{~s}, 54{ }^{\circ} \mathrm{C}, 30 \mathrm{~s}, 72{ }^{\circ} \mathrm{C}, 60 \mathrm{~s}$ for a total of $35 \mathrm{cycles}$; IL-6, $95{ }^{\circ} \mathrm{C}, 30 \mathrm{~s}, 57^{\circ} \mathrm{C}$, $30 \mathrm{~s}, 72{ }^{\circ} \mathrm{C}, 60 \mathrm{~s}$ for a total of 35 cycles; ICAM-1, $95^{\circ} \mathrm{C}, 30 \mathrm{~s}, 57^{\circ} \mathrm{C}, 30 \mathrm{~s}, 72{ }^{\circ} \mathrm{C}, 60 \mathrm{~s}$ for a total of 35 cycles; TARC, $95^{\circ} \mathrm{C}, 30 \mathrm{~s}, 54^{\circ} \mathrm{C}, 30 \mathrm{~s}, 72{ }^{\circ} \mathrm{C}, 60 \mathrm{~s}$ for a total of 35 cycles; MDC, $95{ }^{\circ} \mathrm{C}, 30 \mathrm{~s}, 65^{\circ} \mathrm{C}, 30 \mathrm{~s}$, $72{ }^{\circ} \mathrm{C}, 60 \mathrm{~s}$ for a total of 35 cycles; $\beta$-actin, $95^{\circ} \mathrm{C}, 30 \mathrm{~s}, 60^{\circ} \mathrm{C}, 30 \mathrm{~s}, 72{ }^{\circ} \mathrm{C}, 60 \mathrm{~s}$ for a total of $35 \mathrm{cycles}$. The primer sequences are shown in Table 1.

Table 1. Reverse Transcription-Polymerase Chain Reaction (RT-PCR) primer sequences.

\begin{tabular}{cccc}
\hline Genes & Forward & Reverse & Length (bp) \\
\hline IL-1 $\beta$ & AAAAGCTTGGTGATGTCTGG & TTTCAACACGCAGGACAGG & 176 \\
IL-6 & AGAGTAACTGAGGAACAAGCC & TACATTTGCCGAAGAGCCCT & 238 \\
MDC & AGGACAGAGCATGGCTCGCCTACAGA & TAATGGCAGGGAGGTAGCGCTCCTGA & 361 \\
TARC & CTTCTCTGCAGCACATCC & AAGACCTCTCAAGGCTTTG & 236 \\
ICAM-1 & CACCCTAGAGCCAAGGTGAC & CATTGGACTCTGCTGGGAAT & 251 \\
$\beta-A c t i n$ & GCGGGAAATCGTGCGTGACATT & GATGGAGTTGAAGGTAGTTTCGTG & 231 \\
\hline
\end{tabular}




\subsection{Enzyme-Linked Immunosorbent Assay (ELISA)}

HaCaT cells $\left(1 \times 10^{6}\right.$ cells/well) were treated with TNF- $\alpha /$ IFN- $\gamma$ or with medium alone in the presence or absence of NS or FS for $24 \mathrm{~h}$. The culture medium was harvested and transferred into an ELISA plate. The IL-1 $\beta$ (DLB50; range 3.9-250 pg/mL), IL-6 (6050; range 3.1-800 pg/mL), TARC (DDN00; range 31.2-2000 pg/mL), and MDC (DMD00; range 125.0-4000 pg/mL) produced were measured by an ELISA kit (R\&D system), according to the manufacturer's instructions.

\subsection{Western Blot Analysis}

HaCaT cells $\left(1 \times 10^{6}\right.$ cells/well $)$ were treated with TNF- $\alpha /$ IFN- $\gamma$ or with medium alone in the presence or absence of NS or FS for $30 \mathrm{~min}$ for the detection of IKB- $\alpha$, phospho-NF- $\mathrm{BB}$ p65, and STAT1. The cells were washed twice with PBS and lysed in a lysis buffer (150 mM NaCl, $50 \mathrm{mM}$ Tris- $\mathrm{HCl}, 1 \%$ Trizol, $0.1 \%$ SDS, $0.25 \%$ sodium deoxycholate, and 2-mercaptoethanol) containing protease and phosphatase inhibitors. Equal amounts of protein extracts $(40 \mu \mathrm{g})$ were subjected to $10 \%$ SDS-PAGE, and the resultant gel was transferred to a PVDF membrane. The membrane was incubated with TBS-T buffer ( $\mathrm{pH} 7.5,150 \mathrm{mM} \mathrm{NaCl}, 50 \mathrm{mM}$ Tris- $\mathrm{HCl}$, and $0.1 \%$ Tween 20) containing $5 \%$ skim milk for $1 \mathrm{~h}$, followed by incubation at $4{ }^{\circ} \mathrm{C}$ overnight with the primary antibodies. Subsequently, the membrane was incubated with the secondary antibodies for $1 \mathrm{~h}$ at room temperature. The membrane was washed three times with TBS-T, and color was detected by the PowerOpti-ECL western blotting detection reagent (Bionete, Hwaseong, Korea). The images were captured using the ChemiDoc imaging software (Bio-Rad, Hercules, CA, USA).

\subsection{Statistical Analysis}

All data are presented as means \pm SD (standard deviation) of samples in triplicated samples. The values were analyzed through one-way ANOVA followed by Duncan's multiple range tests using SAS 9.4 (SAS Institute Inc., Cary, NC, USA). The differences were considered statistically significant if $p<0.05$.

\section{Results and Disscusion}

\subsection{Changes in Protein Distribution}

Figure 1 shows the results of the electrophoresis of NS and FS, which are indicative of the protein distribution. The electrophoretic profile of non-fermented sesame (Lane 1) presented high-intensity bands of $2 \mathrm{~S}$ albumin subunits (7, $9 \mathrm{kDA}$, Ses i 1, 2), 7S globulin (45 kDa, Ses i 3), and oleosin subunits $(15,17 \mathrm{kDa}$, Ses i 4, 5). Currently, the five major allergens of sesame include $2 \mathrm{~S}$ albumin and oleosin subunits. The electrophoretic pattern of fermented sesame (lane 2) showed the degradation of all major allergen protein bands. Similarly, Meinlschmidt et al. [17] reported the degradation of major soybean allergens following fermentation with Bacillus subtilis and Lactobacillus helveticus. In addition, the degradation of soybean allergen during fermentation with microbial protease in fermented soybean food has been reported [18]. These results suggest that after fermentation, sesame allergens are degraded into small peptides. Food allergic reactions cause a variety of symptoms associated with the skin and respiratory system. The immunoglobulin E-mediated response has an important role in the pathogenesis of AD. Recent studies have reported the control of allergens through food processing by methods such as genetic modification and heat treatment. However, the sesame allergen Ses i 1 is known to be structurally very stable and is not degraded by heat treatment. Additionally, Moreno et al. [19] reported that Ses i 1 could sufficiently retain its three-dimensional structure while surviving the degradative environment of the gastrointestinal tract in order to sensitize an individual, enhancing the general immunogenicity and provoking an allergic reaction in the sensitized individual. Therefore, sesame fermentation not only enhances antioxidant activities and bioactive compounds, but also effectively reduces allergenicity. 


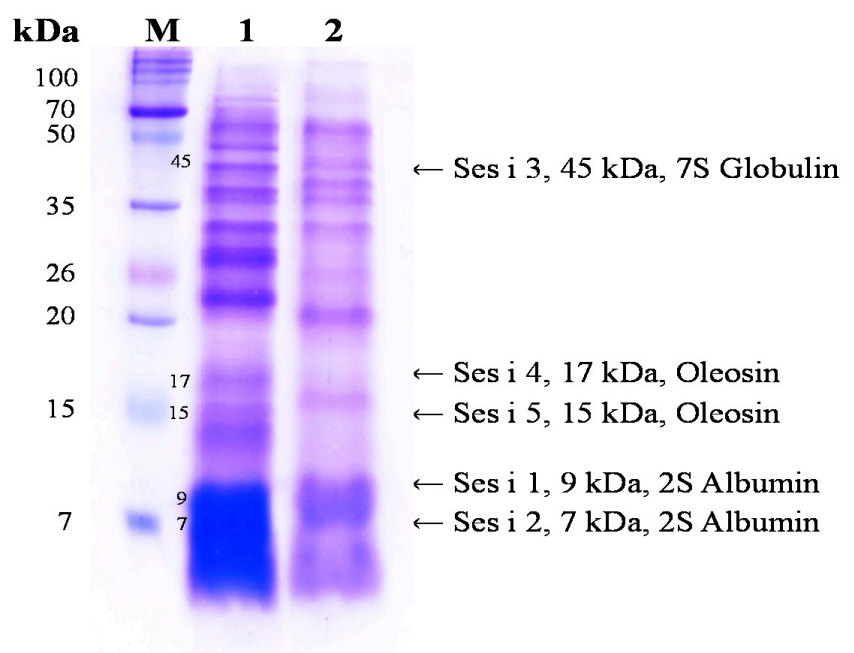

Figure 1. SDS-PAGE analysis of non-fermented sesame (NS) and fermented sesame (FS) proteins. Abbreviations: M, molecular weight standard maker; Lane 1, non-fermented sesame; Lane 2, fermented sesame.

\subsection{Cell Viability}

The compound XTT is cleaved by the mitochondrial dehydrogenase enzyme to produce a dark colored formazan in living cells with active metabolism [20]. To determine the effect of various concentrations of non-fermented sesame (NS) and fermented sesame (FS) on HaCaT cell viability, the XTT assay was used. Figure 2 shows the viability of $\mathrm{HaCaT}$ cells after using different concentrations of NS and FS. In comparison with the control group, the viability of the cells in the presence of NS ranged from 102.83 to $108.94 \%$ and that in the presence of FS ranged from 105.22 to $128.13 \%$, respectively. NS and FS showed no cytotoxic effects on HaCaT cells. In addition, cytotoxicity was not observed in the HaCaT cells treated with TNF- $\alpha / \mathrm{IFN}-\gamma$ and NS or FS. Therefore, we used $200 \mu \mathrm{g} / \mathrm{mL}$ of NS and FS in subsequent experiments.

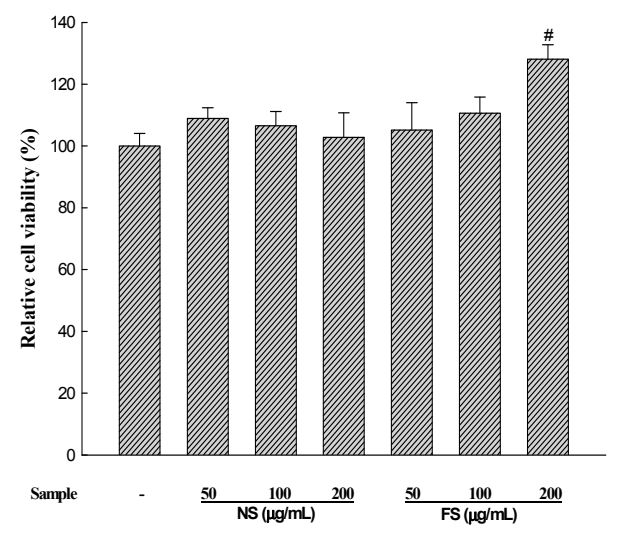

(a)

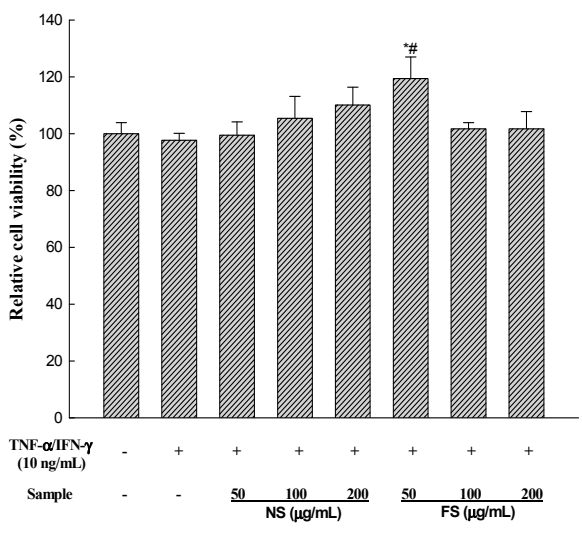

(b)

Figure 2. Effects of NS and FS extracts on cell viability in HaCaT cells. The cells were pre-incubated for $24 \mathrm{~h}$, and cell viability was determined after treatment with NS and FS for $24 \mathrm{~h}$ (a); Cell viability after treatment with TNF- $\alpha / \mathrm{IFN}-\gamma(10 \mathrm{ng} / \mathrm{mL})$ in the presence of NS and FS $(50,100,200 \mu \mathrm{g} / \mathrm{mL})$ was also determined (b). Each bar represents the mean \pm SD of triplicate determinations, $n=3$; \# $p<0.05$ vs. vehicle controls; ${ }^{*} p<0.05,{ }^{* *} p<0.01,{ }^{* * *} p<0.001$ vs. TNF- $\alpha /$ IFN- $\gamma$ treatment alone. 


\section{3. mRNA Expressions of IL-1 $\beta$, IL-6, ICAM-1, TARC, and MDC}

To determine the inhibitory effects of NS and FS on pro-inflammatory cytokine and chemokine mRNA levels, human keratinocyte HaCaT cells were incubated for $24 \mathrm{~h}$ with TNF- $\alpha /$ IFN- $\gamma$ in the presence of NS and FS. As shown in Figure $3 a-f$, the levels of IL-1 $\beta$, IL-6, ICAM-1, TARC, and MDC mRNAs were increased by TNF- $\alpha /$ IFN- $\gamma$ stimulation. The increase in the levels was inhibited following FS treatment. By contrast, NS did not have inhibitory effects on IL-1 $\beta$, IL-6, ICAM-1, TARC, and MDC. The stimulation of HaCaT cells with TNF- $\alpha /$ IFN- $\gamma$ induces the expression of pro-inflammatory cytokines and chemokines.

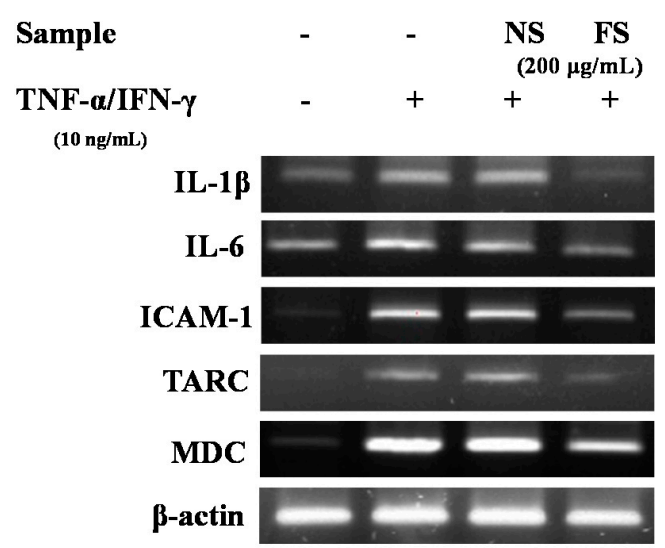

(a)

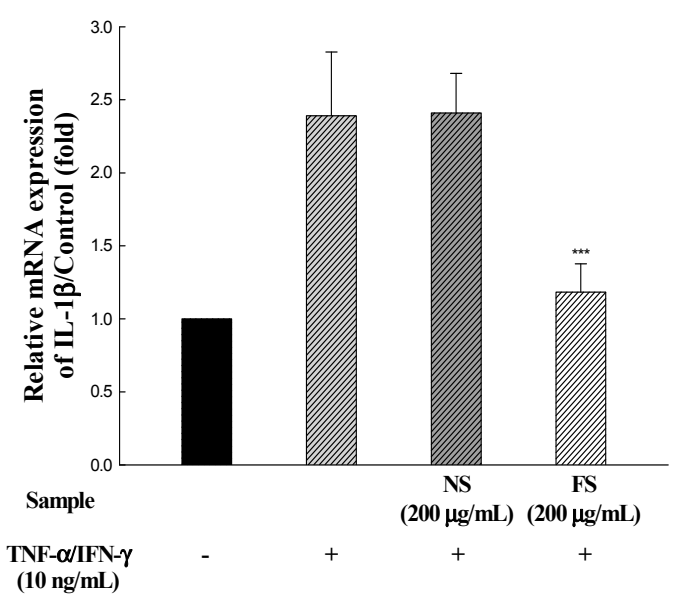

(b)

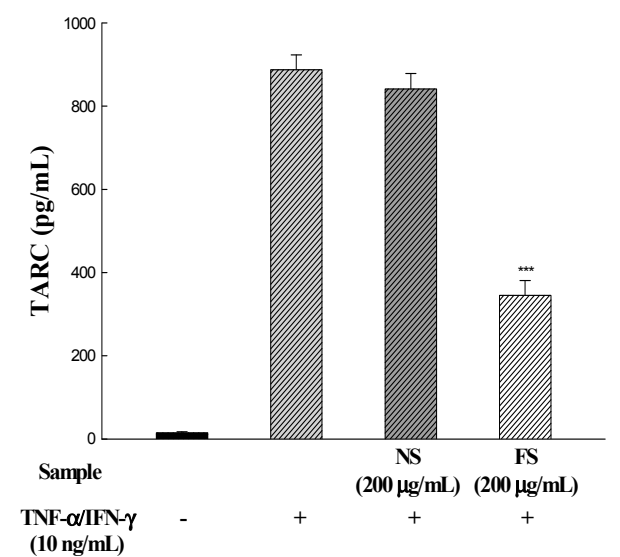

(d)

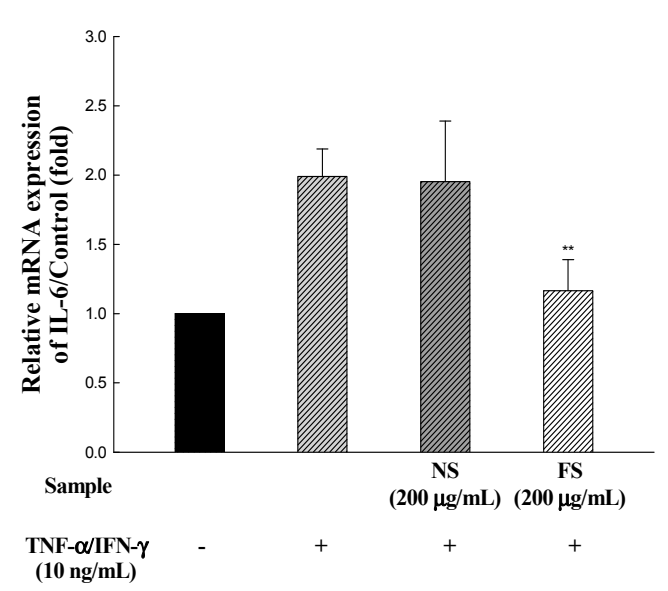

(c)

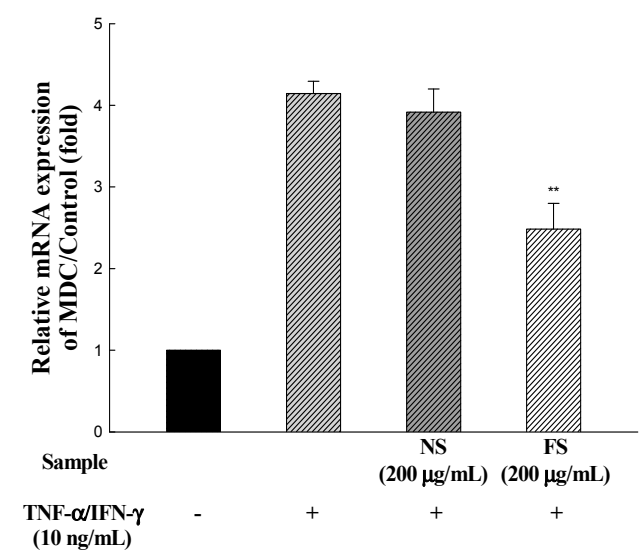

(e)

Figure 3. Cont. 


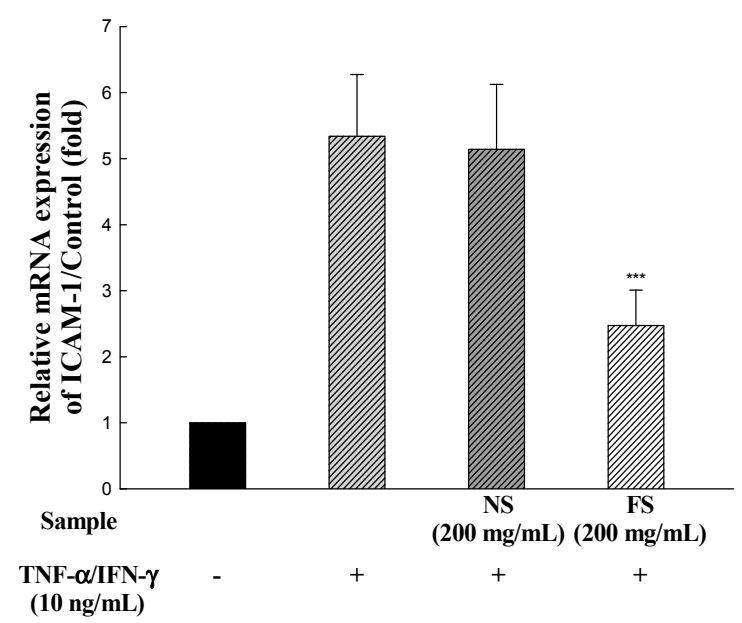

(f)

Figure 3. Effects of NS and FS extracts on TNF- $\alpha /$ IFN- $\gamma$-induced mRNA expression in HaCaT cells. RT-PCR was performed to determine the mRNA expression levels of IL-1 $\beta$, IL-6, ICAM-1, TARC, and MDC (a); The intensities of the PCR bands for IL-1 $\beta$ (b); IL-6 (c); ICAM-1 (d); TARC (e); MDC (f). Each bar represents the mean $\pm \mathrm{SD}$ of triplicate determinations, $n=3 ;^{*} p<0.05,{ }^{* *} p<0.01,{ }^{* * *} p<0.001$ vs. TNF- $\alpha /$ IFN- $\gamma$ treatment alone. + , TNF- $\alpha /$ IFN- $\gamma$ treatment; - , TNF- $\alpha /$ IFN- $\gamma$ untreated.

Chemokines are important in the induction of the inflammatory reaction and immune response. In $\mathrm{AD}$ patients, the infiltration of Th2-type lymphocytes into skin lesions is associated with high-level expression of chemokines such as MDC and TARC [21].

TARC is a chemokine involved in white blood cell infiltration into the skin. CCL17 is considered a pivotal mediator in the inflammatory responses during the development of Th2-dominant inflammatory skin diseases such as $\mathrm{AD}$ [9]. MDC is a chemokine that potently serves as a chemoattractant for monocytes, monocyte-derived dendritic cells, and natural killer cells [22]. The ligands for CCR4 are TARC and MDC, whose levels in the blood of AD patients are closely related to the levels observed during the onset of AD. In addition, the upregulation of ICAM-1 expression in keratinocytes has been observed in several inflammatory dermatoses, such as psoriasis, atopic dermatitis, and lupus erythematosus [23].

Several researchers have reported that the biological activity of natural products might be increased by fermentation. Lee et al. [24] reported that fermented soybean showed higher anti-inflammatory effects on the skin than non-fermented soybean.

\subsection{IL-1 $\beta, I L-6, T A R C$, and MDC Production}

To determine whether NS and FS inhibit TNF- $\alpha /$ IFN- $\gamma$-stimulated IL-1 $\beta$, IL-6, TARC, and MDC production, HaCaT cells were incubated for $24 \mathrm{~h}$ with TNF- $\alpha / \mathrm{IFN}-\gamma$ in the presence of NS and FS, and culture medium supernatants were measured for these pro-inflammatory cytokines and chemokines with an ELISA kit. FS decreased TNF- $\alpha /$ IFN- $\gamma$-induced protein expression of IL-1 $\beta$, IL-6, TARC, and MDC. In contrast, NS did not inhibit IL-1 $\beta$, IL-6, TARC, and MDC protein expression, similar to mRNA expression (Figure $4 a-d$ ). 


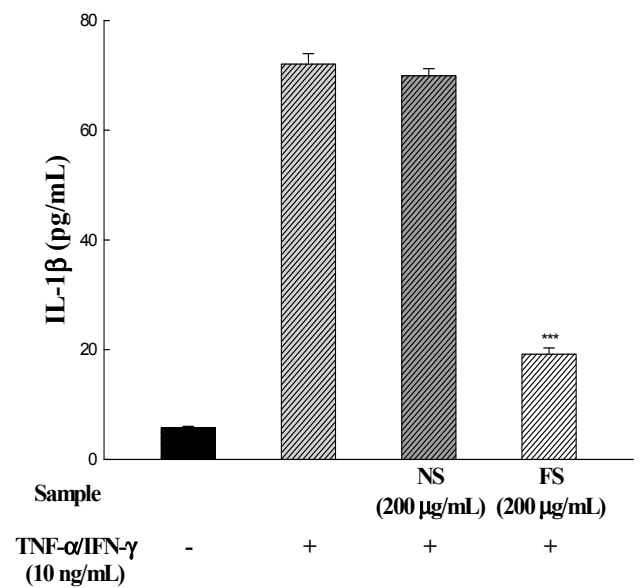

(a)

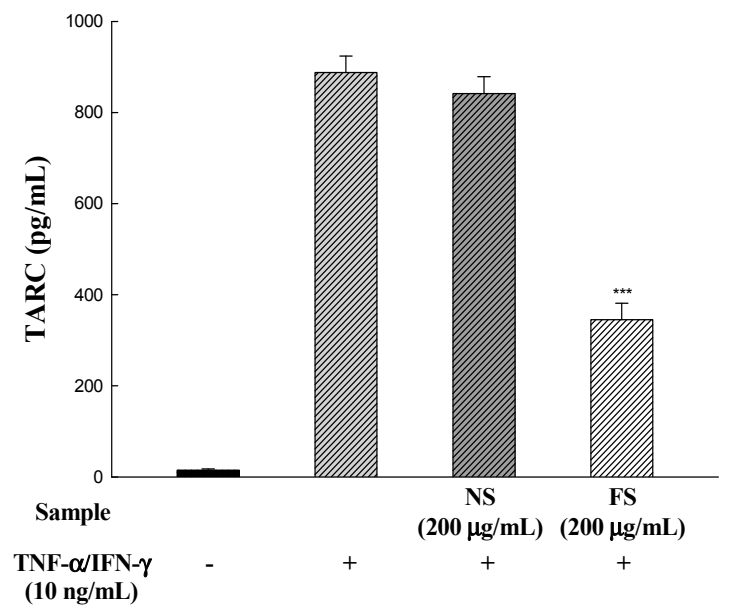

(c)

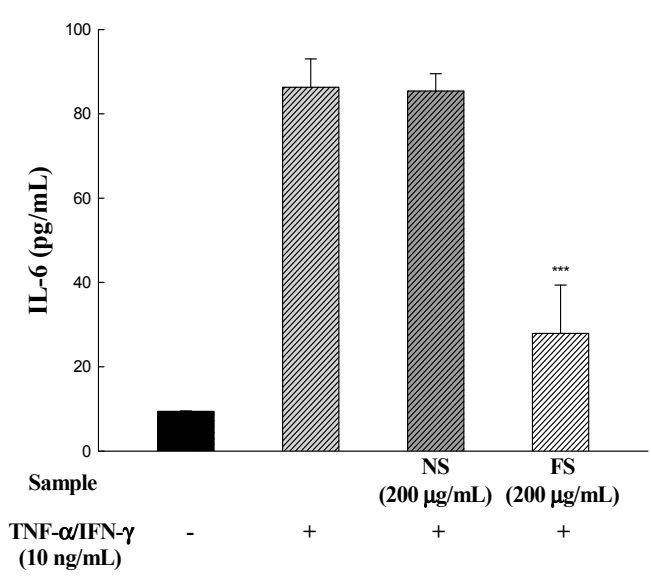

(b)

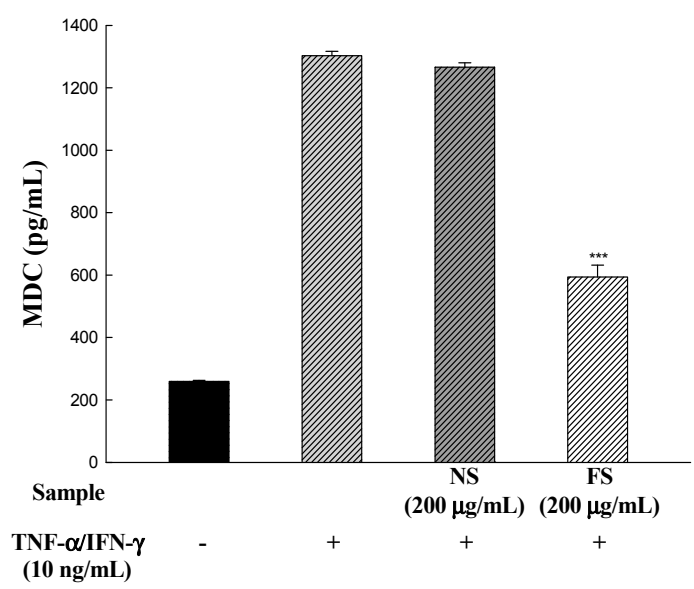

(d)

Figure 4. Effects of NS and FS extracts on TNF- $\alpha /$ IFN- $\gamma$-induced IL- $1 \beta$, IL-6, TARC, and MDC production in HaCaT cells. The production of IL-1 $\beta$ (a); IL-6 (b); TARC (c); MDC (d) protein was measured by ELISA. Each bar represents the mean $\pm \mathrm{SD}$ of triplicate determinations, $n=3$; ${ }^{*} p<0.05,{ }^{* *} p<0.01,{ }^{* * *} p<0.001$ vs. TNF- $\alpha /$ IFN $-\gamma$ treatment alone.,+ TNF- $\alpha /$ IFN- $\gamma$ treatment; - , TNF- $\alpha /$ IFN- $\gamma$ untreated.

IL-6 is known to be acutely expressed at the early stage of inflammation and causes chronic inflammation when its secretion persists. Studies in peritonitis models suggest that IL-6 signaling is of crucial importance in the transition from the acute to the chronic phases of inflammatory processes [25]. In a normal patch test with haptens lesions, the pro-inflammatory cytokine IL-1 $\beta$ is the first detectable cytokine, which induces the migration of Langerhans cells from the epidermal compartment [26]. The pro-inflammatory cytokines IL-6 and IL-1 $\beta$ stimulate keratinocyte proliferation and leukocyte migration. Therefore, FS may regulate the infiltration of Th2 cells into the lesions of the skin by inhibiting mRNA expression and protein production of pro-inflammatory cytokines and chemokines related to $\mathrm{AD}$.

\subsection{Activation of STAT1 and NF- $\kappa B$}

We investigated the effects of NS and FS on the activation of NF-kB and STAT1. The cells were incubated for 30 min with TNF- $\alpha$ /IFN- $\gamma$ in the presence of NS and FS and then analyzed by western blotting. FS inhibited the phosphorylation of NF-kB p65 and the degradation of IкB- $\alpha$ (Figure $5 a$ ), but NS did not show any inhibitory effects. Likewise, FS inhibited the TNF- $\alpha /$ IFN- $\gamma$-induced activation of STAT1 (Figure 5d). 


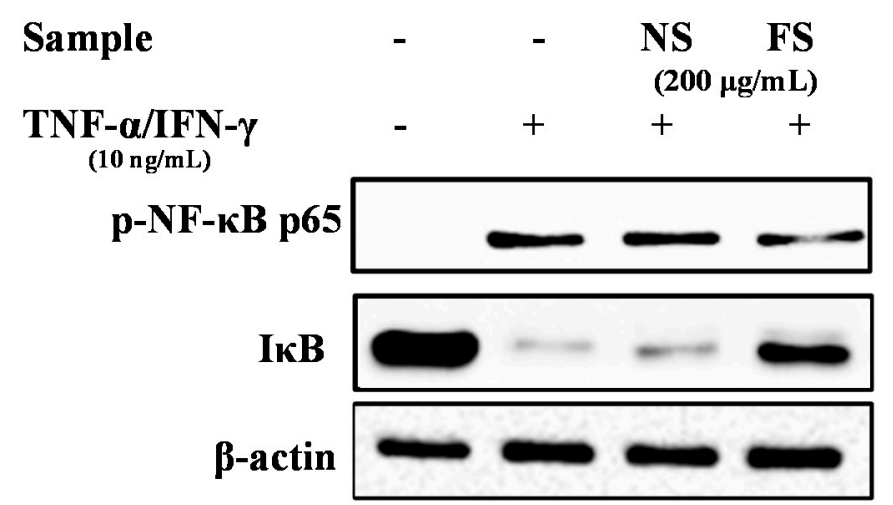

(a)

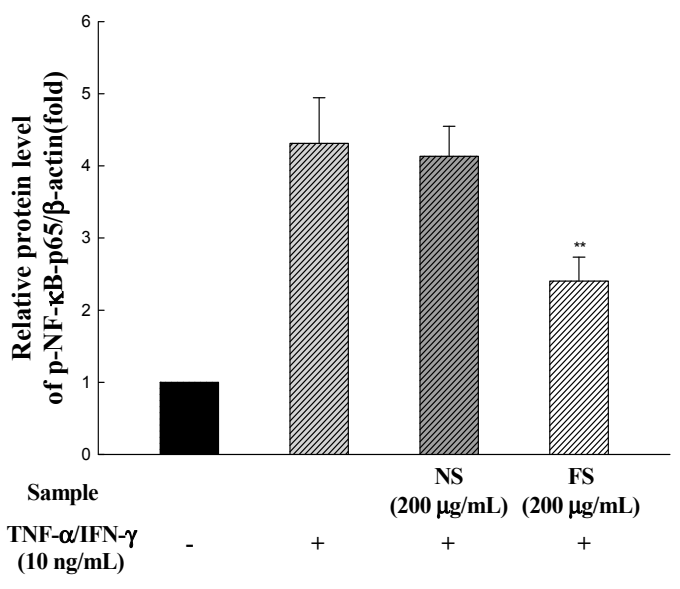

(b)

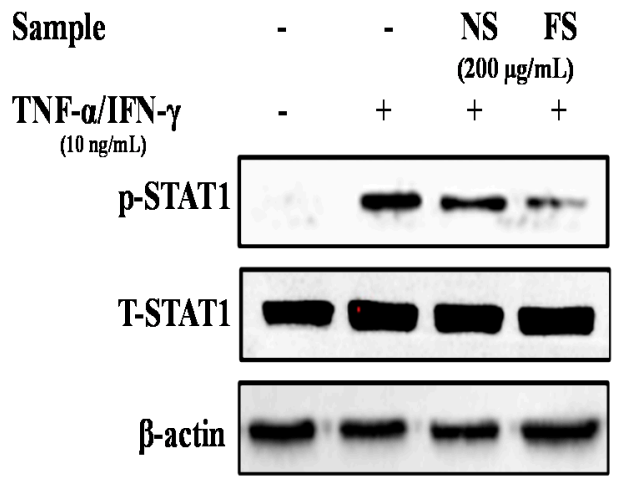

(d)

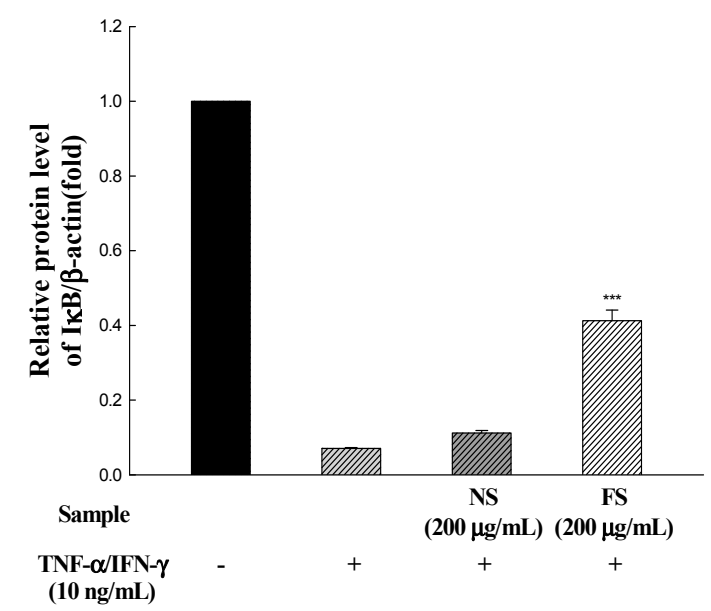

(c)

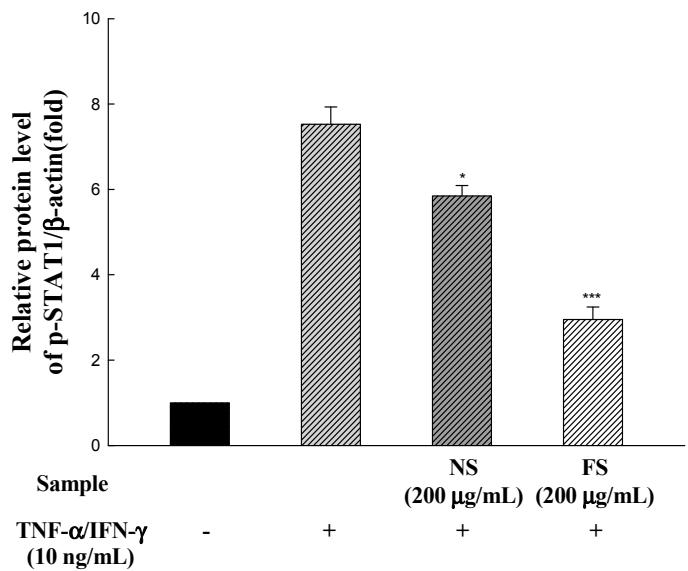

(e)

Figure 5. Effects of NS and FS extracts on TNF- $\alpha /$ IFN- $\gamma$-induced NF- $\mathrm{BB}$ and STAT1 activation in $\mathrm{HaCaT}$ cells. Total protein expression and phospho-NF- $\kappa \mathrm{B}$ and I $\mathrm{B}$ were examined by western blot (a); The relative protein level was calculated for the $\mathrm{p}-\mathrm{NF}-\mathrm{\kappa B} / \beta$-actin $(\mathbf{b})$; The relative protein level was calculated for the I $\mathrm{kB} / \beta$-actin (c); Total protein expression and phosphorylation of STAT1 were examined by western blot (d) and the relative protein level was calculated for p-STAT1/ $\beta$-actin (e). Each bar represents the mean $\pm \mathrm{SD}$ of triplicate determinations, $n=3 ;^{*} p<0.05,{ }^{* *} p<0.01,{ }^{* * *} p<0.001$ vs. TNF- $\alpha /$ IFN- $\gamma$ treatment alone.,+ TNF- $\alpha /$ IFN- $\gamma$ treatment;,- TNF- $\alpha /$ IFN- $\gamma$ untreated.

TARC and MDC promoters contain STAT1 and NF- $\mathrm{kB}$-binding sequences and these transcription factors may mediate the transcription of these genes [27]. NF- $\kappa B$ is a transcription factor that regulates the transcription of genes that are important in the occurrence of inflammatory diseases. 
Phosphorylation of I $\kappa$ B- $\alpha$ by I $\kappa$ B- $\alpha$ kinase (IKK) triggers I $\kappa$ B- $\alpha$ ubiquitinylation and degradation, which liberates NF- $\mathrm{KB}$, allowing it to translocate to the nucleus [28]. STAT1 activation is regulated by the activation of Janus Kinase (JAK). IFN- $\gamma$ activates JAK1/2, which then phosphorylate STAT1 protein [29]. The phosphorylated STAT1 protein is translocated to the nucleus and activates the expression of chemokines such as TARC and MDC. Previous studies showed that NF-KB and JAK/STAT signaling pathways were involved in the regulation of pro-inflammatory cytokine, chemokine, and adhesion molecule production in HaCaT cells [30].

These results indicate that the inhibition of TNF- $\alpha /$ IFN- $\gamma$-induced pro-inflammatory cytokine and chemokine production by FS occurred through the suppression of NF-kB and STAT1 activation. Ju et al. [10] reported that the treatment with 1,2,3,4,6-Penta-O-galloyl- $\beta$-D-glucose alone did not affect mRNA expression, NF- $\mathrm{kB}$, and STAT1 activation in HaCaT cells. In this study, the effects of NS and FS alone on cytokine, chemokine expression, and signaling pathways were not discussed. However, our previous studies showed that antioxidant activity and the amount of bioactive compounds of sesame were increased by bioconversion [13]. Further study is needed to determine the effect of FS treatment alone on TNF- $\alpha /$ IFN- $\gamma$ action.

\section{Conclusions}

In summary, this study evaluated the changes in the anti-allergic activities of NS and FS by bioconversion. The electrophoresis patterns of FS demonstrated the degradation of all major allergen protein bands. FS decreased the protein and mRNA expression of IL-1 $\beta$, IL-6, TARC, and MDC. In contrast, NS did not inhibit the protein and mRNA expression of IL-1 $\beta$, IL-6, TARC, and MDC. We demonstrated that the FS exerts anti-allergic activities by suppressing pro-inflammatory cytokines (IL-1 $\beta$, IL-6) and chemokines (TARC, MDC) through blockade of the phosphorylation of the NF- $\mathrm{BB}$ and STAT1 signaling pathways in HaCaT cells. Thus, fermented sesame products could be developed as a functional food derived from a natural product.

Acknowledgments: This research was supported by iPET (Korea Institute of Planning and Evaluation for Technology in Food, Agriculture, Forestry and Fisheries), the High Value-added Food Technology Development Program (314076-3).

Author Contributions: T.-D.J., D.-B.K., S.J.L., J.-H.L., Y.-C.K. and O.-H.L. designed research; T.-D.J., S.-I.C., S.-H.C., B.-Y.C., W.-S.S., H.-X. and J.-H.L. performed the experiments; T.-D.J. and S.J.P. analyzed the data; T.-D.J., S.-I.C., J.-H.L. and O.-H.L. wrote the paper and edited the paper.

Conflicts of Interest: The authors declare no competing financial interest.

\section{References}

1. Suja, K.P.; Jayalekshmy, A.; Arumughan, C. Antioxidant activity of sesame cake extract. Food Chem. 2005, 91, 213-219. [CrossRef]

2. Kang, M.H.; Naito, M.; Tsujihara, N.; Osawa, T. Sesamolin inhibits lipid peroxidation in rat liver and kidney. J. Nutr. 1998, 128, 1018-1022. [PubMed]

3. Siao, A.C.; Hou, C.W.; Kao, Y.H.; Jeng, K.C. Effect of sesamin on apoptosis and cell cycle arrest in human breast cancer MCF-7 cells. Asian Pac. J. Cancer Prev. 2015, 16, 3779-3783. [CrossRef] [PubMed]

4. Hsu, D.Z.; Chen, K.T.; Li, Y.H.; Chuang, Y.C.; Liu, M.Y. Sesamol delays mortality and attenuates hepatic injury after cecal ligation and puncture in rats: Role of oxidative stress. Shock 2006, 25, 528-532. [CrossRef] [PubMed]

5. Dalal, I.; Goldberg, M.; Katz, Y. Sesame seed food allergy. Curr. Allergy Asthma Rep. 2012, 12, 339-345. [CrossRef] [PubMed]

6. Gangur, V.; Kelly, C.; Navuluri, L. Sesame allergy: A growing food allergy of global proportions? Ann. Allergy Asthma Immunol. 2005, 95, 4-11. [CrossRef]

7. Leduc, V.; Moneret-Vautrin, D.A.; Tzen, J.T.C.; Morisset, M.; Guerin, L.; Kanny, G. Identification of oleosins as major allergens in sesame seed allergic patients. Allergy 2006, 61, 349-356. [CrossRef] [PubMed] 
8. Sebastiani, S.; Albanesi, C.; De Pità, O.; Puddu, P.; Cavani, A.; Girolomoni, G. The role of chemokines in allergic contact dermatitis. Arch. Dermatol. Res. 2002, 293, 552-559. [CrossRef] [PubMed]

9. Saeki, H.; Tamaki, K. Thymus and activation regulated chemokine (TARC)/CCL17 and skin diseases. J. Dermatol. Sci. 2006, 43, 75-84. [CrossRef] [PubMed]

10. Ju, S.M.; Song, H.Y.; Lee, S.J.; Seo, W.Y.; Sin, D.H.; Goh, A.R.; Kang, Y.H.; Kang, I.J.; Won, M.H.; Yi, J.S.; et al. Suppression of thymus-and activation-regulated chemokine (TARC/CCL17) production by 1,2,3,4,6-penta-O-galloyl- $\beta$-D-glucose via blockade of NF- $\kappa$ B and STAT1 activation in the HaCaT cells. Biochem. Biophys. Res. Commun. 2009, 387, 115-120. [CrossRef] [PubMed]

11. Qi, X.F.; Kim, D.H.; Yoon, Y.S.; Li, J.H.; Song, S.B.; Jin, D.; Hunag, X.Z.; Teng, Y.C.; Lee, K.J. The adenylyl cyclase-cAMP system suppresses TARC/CCL17 and MDC/CCL22 production through p38 MAPK and NF-кB in HaCaT keratinocytes. Mol. Immunol. 2009, 46, 1925-1934. [CrossRef] [PubMed]

12. Granato, D.; Branco, G.F.; Cruz, A.G.; Faria, J.D.A.F.; Shah, N.P. Probiotic dairy products as functional foods. Compr. Rev. Food Sci. Food Saf. 2010, 9, 455-470. [CrossRef]

13. Jung, T.D.; Shin, G.H.; Kim, J.M.; Oh, J.W.; Choi, S.I.; Lee, J.H.; Cho, M.L.L.; Lee, S.J.; Heo, I.Y.; Park, S.J.; et al. Changes in Lignan Content and Antioxidant Activity of Fermented Sesame (Sesame indicum L.) by Cultivars. J. Korean Soc. Food Sci. Nutr. 2016, 45, 143-148. [CrossRef]

14. Holzhauser, T.; Wackermann, O.; Ballmer-Weber, B.K.; Bindslev-Jensen, C.; Scibilia, J.; Perono-Garoffo, L.; Utsumi, S.; Poulsen, K.; Vieths, S. Soybean (Glycine max) allergy in Europe: Gly m 5 ( $\beta$-conglycinin) and Gly $\mathrm{m} 6$ (glycinin) are potential diagnostic markers for severe allergic reactions to soy. J. Allergy Clin. Immunol. 2009, 123, 452-458. [CrossRef] [PubMed]

15. El-Ghaish, S.; Ahmadova, A.; Hadji-Sfaxi, I.; El Mecherfi, K.E.; Bazukyan, I.; Choiset, Y.; Rabesona, H.; Sitohy, M.; Popov, G.; Kuliev, A.; et al. Potential use of lactic acid bacteria for reduction of allergenicity and for longer conservation of fermented foods. Trends Food Sci. Technol. 2011, 22, 509-516. [CrossRef]

16. Laemmli, U.K. Cleavage of structural proteins during the assembly of the head of bacteriophage T4. Nature 1970, 227, 680-685. [CrossRef] [PubMed]

17. Meinlschmidt, P.; Ueberham, E.; Lehmann, J.; Schweiggert-Weisz, U.; Eisner, P. Immunoreactivity, sensory and physicochemical properties of fermented soy protein isolate. Food Chem. 2016, 205, 229-238. [CrossRef] [PubMed]

18. Song, Y.S.; Pérez, V.G.; Pettigrew, J.E.; Martinez-Villaluenga, C.; de Mejia, E.G. Fermentation of soybean meal and its inclusion in diets for newly weaned pigs reduced diarrhea and measures of immunoreactivity in the plasma. Anim. Feed Sci. Technol. 2010, 159, 41-49. [CrossRef]

19. Moreno, F.J.; Maldonado, B.M.; Wellner, N.; Mills, E.C. Thermostability and in vitro digestibility of a purified major allergen $2 \mathrm{~S}$ albumin (Ses i 1 ) from white sesame seeds (Sesamum indicum L.). Biochim. Biophys. Acta 2005, 1752, 142-153. [CrossRef] [PubMed]

20. Roehm, N.W.; Rodgers, G.H.; Hatfield, S.M.; Glasebrook, A.L. An improved colorimetric assay for cell proliferation and viability utilizing the tetrazolium salt XTT. J. Immunol. Methods 1991, 142, 257-265. [CrossRef]

21. Spergel, J.M.; Boguniewicz, M.; Schneider, L.; Hanifin, J.M.; Paller, A.S.; Eichenfield, L.F. Food allergy in infants with atopic dermatitis: Limitations of food-specific IgE measurements. Am. Acad. Pediatr. 2015, 136, 1-9. [CrossRef] [PubMed]

22. Godiska, R.; Chantry, D.; Raport, C.J.; Sozzani, S.; Allavena, P.; Leviten, D.; Mantovani, A.; Gray, P.W. Human macrophage-derived chemokine (MDC), a novel chemoattractant for monocytes, monocyte-derived dendritic cells, and natural killer cells. J. Exp. Med. 1997, 185, 1595-1604. [CrossRef] [PubMed]

23. Bito, T.; Roy, S.; Sen, C.K.; Packer, L. Pine bark extract pycnogenol downregulates IFN- $\gamma$-induced adhesion of T cells to human keratinocytes by inhibiting inducible ICAM-1 expression. Free Radic. Biol. Med. 2000, 28, 219-227. [CrossRef]

24. Lee, T.H.; Do, M.H.; Oh, Y.L.; Cho, D.W.; Kim, S.H.; Kim, S.Y. Dietary fermented soybean suppresses UVB-induced skin inflammation in hairless mice via regulation of the MAPK signaling pathway. J. Agric. Food Chem. 2014, 62, 8962-8972. [CrossRef] [PubMed]

25. Hurst, S.M.; Wilkinson, T.S.; McLoughlin, R.M.; Jones, S.; Horiuchi, S.; Yamamoto, N.; Rose-John, S.; Fuller, M.; Topley, N.; Jones, A. Il-6 and its soluble receptor orchestrate a temporal switch in the pattern of leukocyte recruitment seen during acute inflammation. Immunity 2001, 146, 705-714. [CrossRef] 
26. Enk, A.H.; Angeloni, V.L.; Udey, M.C.; Katz, S.I. An essential role for Langerhans cell-derived IL-1 beta in the initiation of primary immune responses in skin. J. Immunol. 1993, 150, 3698-3704. [PubMed]

27. Nakayama, T.; Hieshima, K.; Nagakubo, D.; Sato, E.; Nakayama, M.; Kawa, K.; Yoshie, O. Selective induction of Th2-attracting chemokines CCL17 and CCL22 in human B cells by latent membrane protein 1 of Epstein-Barr virus. Br. J. Virol. 2004, 78, 1665-1674. [CrossRef]

28. Kim, H.H.; Lee, Y.; Eun, H.C.; Chung, J.H. Eicosapentaenoic acid inhibits TNF- $\alpha$-induced matrix metalloproteinase-9 expression in human keratinocytes, HaCaT cells. Biochem. Biophys. Res. Commun. 2008, 368, 343-349. [CrossRef] [PubMed]

29. Choi, J.H.; Jin, S.W.; Han, E.H.; Park, B.H.; Kim, H.G.; Khanal, T.; Hwang, Y.P.; Do, M.T.; Lee, H.S.; Chung, Y.C.; et al. Platycodon grandiflorum root-derived saponins attenuate atopic dermatitis-like skin lesions via suppression of NF- $\mathrm{KB}$ and STAT1 and activation of Nrf2/ARE-mediated heme oxygenase-1. Phytomedicine 2014, 21, 1053-1061. [CrossRef] [PubMed]

30. Choi, H.J.; Lee, J.H.; Jung, Y.S. (+)-Nootkatone inhibits tumor necrosis factor $\alpha /$ interferon $\gamma$-induced production of chemokines in HaCaT cells. Biochem. Biophys. Res. Commun. 2014, 447, 278-284. [CrossRef] [PubMed]

(C) 2018 by the authors. Licensee MDPI, Basel, Switzerland. This article is an open access article distributed under the terms and conditions of the Creative Commons Attribution (CC BY) license (http:/ / creativecommons.org/licenses/by/4.0/). 